Check for updates

Cite this: RSC Adv., 2017, 7, 48745

\title{
Synthesis of bis-(benzocyclohexan-ketoimino) Ni(I) with different electron groups and their catalytic copolymerization of norbornene and polar norbornene $\uparrow$
}

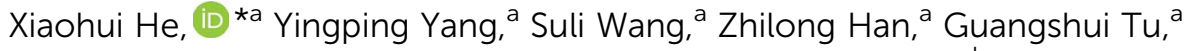 \\ Feng Zhang, ${ }^{a}$ Shengmei Huang, ${ }^{\text {ac }}$ Zijie Wang ${ }^{a}$ and Defu Chen ${ }^{b}$
}

Four N,O-chelating type bidentate ligand nickel(॥) complexes, $\mathrm{Ni}\left\{\mathrm{C}_{10} \mathrm{H}_{8}(\mathrm{O}) \mathrm{C}[\mathrm{ArN}] \mathrm{CH}_{3}\right\}_{2}$, two of them containing electron-donating groups ( $\mathrm{Ni1}: \mathrm{Ar}=p-\mathrm{PhCH}_{3}, \mathrm{Ni2}$ : $\mathrm{Ar}=p-\mathrm{PhOCH}_{3}$ ) and another two containing electron-withdrawing groups ( $\mathrm{Ni3}: \mathrm{Ar}=p-\mathrm{PhF}, \mathrm{Ni} 4: \mathrm{Ar}=p-\mathrm{PhCF}_{3}$ ), were synthesized and the molecular structures of $\mathrm{Ni2}, \mathrm{Ni} 3$ and $\mathrm{Ni} 4$ were determined by $\mathrm{X}$-ray crystallography. Copolymerization of norbornene (NB) and 5-norbornene-2-carboxylic acid methyl ester $\left(\mathrm{NB}-\mathrm{COOCH}_{3}\right)$ were carried out in toluene with the above complexes as catalyst precursors and $\mathrm{B}\left(\mathrm{C}_{6} \mathrm{~F}_{5}\right)_{3}$ as the co-catalyst. All complexes showed high catalytic activity toward the copolymerization (up to $2.80 \times 10^{5}$ g polymer $\mathrm{mol}_{\mathrm{Ni}}{ }^{-1} \mathrm{~h}^{-1}$ ) and the complexes with electron-withdrawing groups ( $\mathrm{Ni3}$ and $\mathrm{Ni4}$ ) showed higher catalytic activity, and the activity was enhanced with the increased electron-withdrawing ability of the substituent (Ni4 > Ni3). The obtained poly(NB-CO-NB-COOCH )s were confirmed to be vinyl-addition copolymers and noncrystalline. All copolymers exhibited better solubility in common organic solvents, and showed high molecular weights (up to the grade of $10^{5} \mathrm{~g} \mathrm{~mol}^{-1}$ ) and good thermal stability $\left(T_{d}>370{ }^{\circ} \mathrm{C}\right.$ ). Meanwhile, variation of the substituted electron group could slightly affect the above-mentioned copolymers' properties.

Received 6th September 2017 Accepted 4th October 2017

DOI: $10.1039 / c 7 r a 09944 d$

rsc.li/rsc-advances

\section{Introduction}

Cyclic olefin copolymers (COCs) as a good candidate for engineering plastics and optical apparatus have aroused great attention from both science and industry over the past decade. ${ }^{1,2}$ Cyclic olefin polymers are usually produced by addition polymerization and ring-opening metathesis polymerization, and the addition polymerization will not destroy the ring structure of the monomer itself. Norbornene (NB) and its derivatives are polymerizable owing to the existence of ring strain, thus norbornene has become one of the most active participants in cyclo-olefin copolymerization. ${ }^{3,4}$ Vinyl-type polynorbornene (PNB) does not contain any double bonds and with a rotationally strongly constrained configuration, ${ }^{5}$ which consists of rigid alicyclic polymer backbone, it features many

${ }^{a}$ School of Materials Science and Engineering, Nanchang University, 999 Xuefu Avenue, Nanchang 330031, China. E-mail: hexiaohui@ncu.edu.cn

${ }^{b}$ School of Civil Engineering and Architecture, Nanchang University, 999 Xuefu Avenue, Nanchang 330031, China

'School of Materials Science and Engineering, Nanchang Hangkong University, Nanchang 330063, China

$\dagger$ CCDC 1505523, 1505524 and 1505512 for Ni2, Ni3 and Ni4, respectively. For crystallographic data in CIF or other electronic format see DOI: $10.1039 / \mathrm{c} 7 \mathrm{ra09944d}$ advantageous qualities, such as high thermal stability, high glass transition temperatures $\left(T_{\mathrm{g}}\right)$, high optical transparency, large refractive index, low birefringence, low dielectric constant, low moisture absorption as well as low cost. These advantages have been widely applied in many microelectronic and optical applications. ${ }^{6}$ However, the widespread application of PNB has been hampered by its low solubility, mechanical brittleness as well as poor processability. It has been reported that PNB obtained by nickel catalysts could be dissolved in chlorobenzene at room temperature in the 2000 s, and the solubility and processability of PNB have been improved. ${ }^{5,7}$ Introducing polar groups $^{8-11}$ or flexible chains ${ }^{12,13}$ into the PNB backbone has become an effective means of solving the problem. The design and synthesis of particularly efficient and stable catalysts is very important for the polymerization. It is generally known that the vinyl-type polynorbornene can be efficiently obtained by using traditional Ziegler-Natta catalysts $\left(\mathrm{TiCl}_{4}, \mathrm{TiCl}_{3}\right),{ }^{14,15}$ metallocene catalysts (Ti, Zr, Hf), ${ }^{16,17}$ and late transition metal catalysts ( $\mathrm{Ni}$, $\mathrm{Pd}, \mathrm{Fe}, \mathrm{Co}, \mathrm{Cu}){ }^{18-29}$ Among these catalysts, the late transition metal catalysts have attracted more attention owing to their lower oxophilicity, higher catalytic activity, and better stability in polar solvents. The most common late transition metal catalysts are $\mathrm{Ni}$ (II) and $\mathrm{Pd}(\mathrm{II})$ complexes. Ni(II) complexes endow the catalysts with the ability to produce copolymers with 
a variety of polar functionalized olefins, allowing the preparation of complex functional polymer architectures. ${ }^{30} \mathrm{Ni}$ (II) complexes are the most frequently used catalyst species because of the better catalytic performances and stability than that of Pd(II) complexes and illustrated reaction mechanisms. In recent years, $\beta$-ketoimino metal complexes have drawn wide attention from researchers owing to the remarkable simplicity of ligand syntheses and rich opportunities for fine-tuning of their steric and electronic properties. These complexes exhibit excellent activity and good tolerance to polar groups toward the functionalized vinyl-type polynorbornene in the presence of MAO, modified MAO (MMAO), or $\mathrm{B}\left(\mathrm{C}_{6} \mathrm{~F}_{5}\right)_{3} \cdot{ }^{31-33}$ Our group have also synthesized and characterized a series of $\beta$-ketoimino nickel and palladium complexes that could effectively catalyze copolymerization of norbornene (NB) and NB derivatives. ${ }^{34-39}$ However, the important ligand-designing parameters, steric and electronic factors, were not completely involved in our previous reports. In this work, we aimed to further examine the impact of electronic effects on the catalytic activity. To this end, we prepared four $\beta$-ketoimino nickel complexes (Ni1-Ni4), of which two contain electron-donating groups (Ni1, Ni2) and another two contain electron-withdrawing groups (Ni3, Ni4), and compared their activities via the copolymerization of $\mathrm{NB}$ and $\mathrm{NB}-\mathrm{COOCH}_{3}$ upon activation with $\mathrm{B}\left(\mathrm{C}_{6} \mathrm{~F}_{5}\right)_{3}$. All complexes appeared to be highly active catalysts, and the catalytic activities of Ni3 and Ni4 are higher than those of Ni1 and Ni2. The properties of the obtained polymers, such as molecular weight, solubility and thermal stability, were slightly affected by variation of the substituted electron group. X-ray structures of Ni2, Ni3 and Ni4 were acquired.

\section{Experimental}

\subsection{Materials}

All operations with water and oxygen-sensitive compounds were performed under a dry nitrogen atmosphere using Schlenk lines or a glove box (M Braun), and all solvents were dehydrated before use. Toluene and tetrahydrofuran (THF) were dried over sodium/benzophenone and distilled under dry nitrogen. Norbornene (NB) was purchased from Alfa Aesar and purified by drying over sodium and distilling at $110{ }^{\circ} \mathrm{C}$ under nitrogen atmosphere, used as a solution $\left(0.4 \mathrm{~g} \mathrm{~mL}^{-1}\right)$ in toluene. 5Norbornene-2-carboxylic acid methyl ester $\left(\mathrm{NB}-\mathrm{COOCH}_{3}\right)$ was purchased from energy chemical and purified by distillation over $\mathrm{CaH}_{2}$ at a reduced pressure under dry nitrogen atmosphere.

\subsection{Measurements}

The structures of the ligands and polymers were characterized by ${ }^{1} \mathrm{H}$ and ${ }^{13} \mathrm{C}$ NMR spectra, which were recorded on a Bruker ARX 400 NMR spectrometer at room temperature in $\mathrm{CDCl}_{3}$ using tetramethylsilane (TMS) as the internal standard. The FTIR spectra were recorded using a Shimadzu IR Prestige-21 FTIR spectrophotometer and average data were obtained from the standard wave number range from 500 to $4000 \mathrm{~cm}^{-1}$. The molecular weight and molecular weight distribution of the polymers were determined by gel permeation chromatography (PL-GPC220), with a refractive index detector using tetrahydrofuran as the eluent with a flow rate of $0.5 \mathrm{~mL} \mathrm{~min}^{-1}$ and the detector at $40{ }^{\circ} \mathrm{C}$.

The wide-angle X-ray diffraction (WXRD) curves were obtained on a Bruker D8 Focus X-ray diffractometer, operating at $40 \mathrm{kV}$ and $40 \mathrm{~mA}$ with a copper target $(\lambda=1.54 \AA)$ at a scanning rate of $2^{\circ} \mathrm{min}^{-1}$ from $3^{\circ}$ to $50^{\circ}$. Thermal gravimetric analysis (TGA) was performed on a PerkinElmer TA-600 under nitrogen atmosphere from room temperature to $650{ }^{\circ} \mathrm{C}$ at a heating rate of $10{ }^{\circ} \mathrm{C} \mathrm{min}{ }^{-1}$, and $5 \%$ loss of the polymer weight was used to evaluate its thermal stability. The differential scanning calorimetry (DSC) measurements were obtained on a Shimadzu DSC-60 with a heating-cooling rate of $10{ }^{\circ} \mathrm{C} \min ^{-1}$ under a nitrogen atmosphere.

\subsection{Crystal structure determination}

The X-ray diffraction data of single crystals of the complexes were obtained using the $\omega-2 \theta$ scan mode on a Bruker Smart APEX II CCD diffractometer with graphite-monochromated Mo $\mathrm{K} \alpha$ radiation $(\lambda=0.71073)$. The structures were solved by direct methods, and further refinements with full-matrix least-squares on $F^{2}$ were obtained with the SHELXTL program package. All non-hydrogen atoms were refined anisotropically.

\subsection{Syntheses of ligands (L1-L4) and nickel complexes (Ni1- Ni4)}

N,O-Chelating type ligands and their bidentate nickel complexes were synthesized referring to the synthetic procedure reported by our group ${ }^{\mathbf{4 0}}$ and shown in Scheme 1.

Synthesis of $\mathbf{C}_{10} \mathbf{H}_{8}(\mathbf{O}) \mathbf{C}\left[\mathbf{H N}\left(p-\mathbf{P h C H}_{3}\right)\right] \mathbf{C H}_{3}(\mathrm{L1})$. To a $250 \mathrm{~mL}$, round-bottomed flask equipped with a magnetic stir bar was added 2-acetyl-1-tetralone (1.88 g, $0.01 \mathrm{~mol}), p$-methylaniline $(1.07 \mathrm{~g}, 0.01 \mathrm{~mol})$, a catalytic amount of $p$-toluene-sulfonic acid and toluene $(150 \mathrm{~mL})$. The mixture was heated to reflux for $5 \mathrm{~h}$, while water was removed as a toluene azeotrope at $125^{\circ} \mathrm{C}$ using a water separator. The resulting solution was evaporated under vacuum to remove the residual toluene (concentrated to 4-5 $\mathrm{mL}$ ), then the raw mixture was purified by column

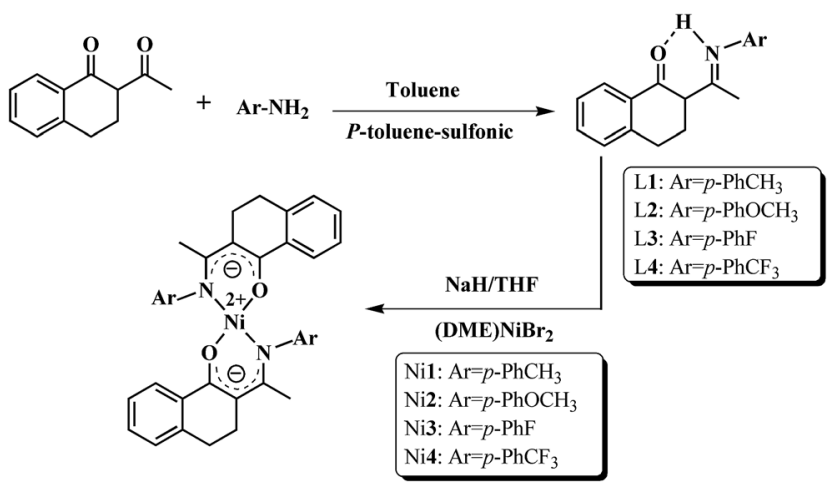

Scheme 1 The synthetic routes for the benzocyclohexan-ketoimine ligands (L1-L4) and bis-(benzocyclohexan-ketoimino) Ni(॥) complexes (Ni1-Ni4). 
chromatography with n-hexane and ethyl acetate (20/1 in v/v). After concentration, yellow crystals were finally obtained.

Yield: $1.68 \mathrm{~g}$ (57.4\%). ${ }^{1} \mathrm{H}$ NMR $\left(\mathrm{CDCl}_{3}, \delta, \mathrm{ppm}\right): 14.06(\mathrm{~s}, 1 \mathrm{H}$, $\mathrm{O} \cdots \mathrm{H}-\mathrm{N})$; 7.27-8.07 (m, $\left.4 \mathrm{H}, \mathrm{C}_{10} \mathrm{H}_{8}\right) ; 6.97-7.22\left(\mathrm{~m}, 4 \mathrm{H}, \mathrm{C}_{6} \mathrm{H}_{4}\right)$; 2.56-2.96 (m, 4H, C $\left.{ }_{10} \mathrm{H}_{8}\right) ; 2.35$ (m, 3H, R- $\left.\mathrm{CH}_{3}\right) ; 2.10$ (s, 3H, $\left.\mathrm{CH}_{3}\right)$.

Synthesis of $\mathrm{C}_{10} \mathrm{H}_{8}(\mathrm{O}) \mathrm{C}\left[\mathrm{HN}\left(p-\mathrm{PhOCH}_{3}\right)\right] \mathrm{CH}_{3}(\mathrm{~L} 2)$. Analogous to the synthetic route of $\mathrm{L} 1, p$-methylaniline was substituted by $p$-methoxyaniline and yellow crystals were obtained.

Yield: $1.49 \mathrm{~g}$ (48.4\%). ${ }^{1} \mathrm{H} \mathrm{NMR}\left(\mathrm{CDCl}_{3}, \delta, \mathrm{ppm}\right): 13.99(\mathrm{~s}, 1 \mathrm{H}$, $\mathrm{O} \cdots \mathrm{H}-\mathrm{N})$; 7.12-8.06 (m, 4H, $\left.\mathrm{C}_{10} \mathrm{H}_{8}\right) ; 6.81-7.10\left(\mathrm{~m}, 4 \mathrm{H}, \mathrm{C}_{6} \mathrm{H}_{4}\right)$; 2.59-2.94 (m, $\left.4 \mathrm{H}, \mathrm{C}_{10} \mathrm{H}_{8}\right) ; 3.80\left(\mathrm{~s}, 3 \mathrm{H}, \mathrm{OCH}_{3}\right) ; 2.06\left(\mathrm{~s}, 3 \mathrm{H}, \mathrm{CH}_{3}\right)$.

Synthesis of $\mathrm{C}_{10} \mathrm{H}_{\mathbf{8}}(\mathrm{O}) \mathrm{C}[\mathrm{HN}(p-\mathrm{PhF})] \mathrm{CH}_{3}$ (L3). Analogous to the synthetic route of $\mathrm{L} 1, p$-methylaniline was substituted by $p$ fluoroaniline and yellow crystals were obtained.

Yield: $1.92 \mathrm{~g}$ (68.4\%). ${ }^{1} \mathrm{H}$ NMR $\left(\mathrm{CDCl}_{3}, \delta, \mathrm{ppm}\right): 14.01(\mathrm{~s}, 1 \mathrm{H}$, $\mathrm{O} \cdots \mathrm{H}-\mathrm{N})$; 7.26-8.01 (m, $\left.4 \mathrm{H}, \mathrm{C}_{10} \mathrm{H}_{8}\right) ; 6.98-7.22\left(\mathrm{~m}, 4 \mathrm{H}, \mathrm{C}_{6} \mathrm{H}_{4}\right)$; 2.58-2.93 (m, $\left.4 \mathrm{H}, \mathrm{C}_{10} \mathrm{H}_{8}\right) ; 2.08\left(\mathrm{~s}, 3 \mathrm{H}, \mathrm{CH}_{3}\right)$.

Synthesis of $\mathrm{C}_{10} \mathrm{H}_{8}(\mathrm{O}) \mathrm{C}\left[\mathrm{HN}\left(p-\mathrm{PhCF}_{3}\right)\right] \mathrm{CH}_{3}(\mathrm{~L} 4)$. Analogous to the synthetic route of $\mathrm{L} 1, p$-methylaniline was substituted by $p$ trifluoromethylaniline and yellow crystals were obtained.

Yield: $2.06 \mathrm{~g}$ (60.3\%). ${ }^{1} \mathrm{H} \mathrm{NMR}\left(\mathrm{CDCl}_{3}, \delta, \mathrm{ppm}\right): 14.13(\mathrm{~s}, 1 \mathrm{H}$, $\mathrm{O} \cdots \mathrm{H}-\mathrm{N}) ; 7.27-8.08\left(\mathrm{~m}, 4 \mathrm{H}, \mathrm{C}_{10} \mathrm{H}_{8}\right) ; 6.67-7.23\left(\mathrm{~m}, 4 \mathrm{H}, \mathrm{C}_{6} \mathrm{H}_{4}\right)$; 2.50-2.95 (m, $\left.4 \mathrm{H}, \mathrm{C}_{10} \mathrm{H}_{8}\right) ; 2.23\left(\mathrm{~s}, 3 \mathrm{H}, \mathrm{CH}_{3}\right)$.

Synthesis of $\mathrm{Ni}\left\{\mathrm{C}_{10} \mathrm{H}_{8}(\mathrm{O}) \mathrm{C}\left[\mathrm{N}\left(p-\mathrm{PhCH}_{3}\right)\right] \mathrm{CH}_{3}\right\}_{2}(\mathrm{Ni1})$. To a $100 \mathrm{~mL}$, round-bottomed flask equipped with a magnetic stir bar was added L1 $(0.554 \mathrm{~g}, 0.002 \mathrm{~mol})$ and THF $(20 \mathrm{~mL})$ under nitrogen protection. When the ligand dissolved completely, $0.08 \mathrm{~g}$ of $\mathrm{NaH}(60 \%, 0.002 \mathrm{~mol})$ was added under a dry nitrogen atmosphere. After being stirred vigorously for $8 \mathrm{~h}$ at room temperature, the solution changed to orange color and the excess THF was removed in vacuo. After that, (DME) $\mathrm{NiBr}_{2}$ was introduced under an atmosphere of dry and oxygen-free nitrogen, then dichloromethane $(20 \mathrm{~mL})$ was injected and the reacting mixture immediately turned to green color. After being stirred vigorously for $24 \mathrm{~h}$ at room temperature, the precipitate was separated by filtration and concentrated, and the darkgreen nickel complex (Ni1) was obtained in $70 \%$ yield.

Synthesis of $\mathrm{Ni}\left\{\mathrm{C}_{10} \mathrm{H}_{8}(\mathrm{O}) \mathrm{C}\left[\mathrm{N}\left(p-\mathrm{PhOCH}_{3}\right)\right] \mathrm{CH}_{3}\right\}_{2}$ (Ni2). Ni2 was prepared according to a similar procedure to that for Ni1 and was obtained as a dark-green crystal in 58\% yield.

Synthesis of $\mathbf{N i}\left\{\mathrm{C}_{10} \mathrm{H}_{\mathbf{8}}(\mathrm{O}) \mathbf{C}[\mathbf{N}(\boldsymbol{p}-\mathrm{PhF})] \mathrm{CH}_{3}\right\}_{2}$ (Ni3). Ni3 was prepared according to a similar procedure to that for Ni1 and obtained as a green crystal in $64 \%$ yield.

Synthesis of $\mathrm{Ni}\left\{\mathrm{C}_{\mathbf{1 0}} \mathrm{H}_{\mathbf{8}}(\mathrm{O}) \mathrm{C}\left[\mathrm{N}\left(\boldsymbol{p}-\mathrm{PhCF}_{3}\right)\right] \mathrm{CH}_{3}\right\}_{2}$ (Ni4). Ni4 was prepared according to a similar procedure to that for $\mathrm{Ni1}$ and was obtained as a dark-green crystal in $44 \%$ yield.

\subsection{Polymerization}

All experimental manipulations were performed under a dry nitrogen atmosphere. NB and $\mathrm{NB}-\mathrm{COOCH}_{3}$ (the total amount was kept at $0.01 \mathrm{~mol}$ ) were added to a $100 \mathrm{~mL}$ two-necked roundbottom flask containing a magnetic stir bar. The nickel complex Ni1-Ni4 $\left(5 \times 10^{-6} \mathrm{~mol}\right)$ solutions were added by syringe followed by $\mathrm{B}\left(\mathrm{C}_{6} \mathrm{H}_{5}\right)_{3}\left(1.0 \times 10^{-4} \mathrm{~mol}\right)$. The solution was continuously stirred for $30 \mathrm{~min}$ at $60{ }^{\circ} \mathrm{C}$. The reaction was terminated by addition of methanol/hydrochloric acid $\left(V_{\mathrm{m}} / V_{\mathrm{H}}=9 / 1\right)$ and

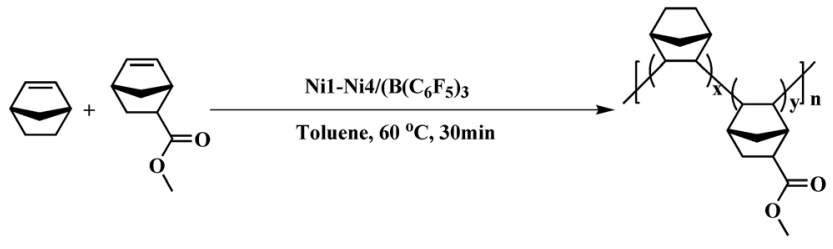

Scheme 2 Copolymerization of NB and NB-COOCH 3 catalyzed by $\mathrm{Ni1}-\mathrm{Ni} 4 / \mathrm{B}\left(\mathrm{C}_{6} \mathrm{~F}_{5}\right)_{3}$

was stayed over $12 \mathrm{~h}$. After filtering and washing with methanol several times, the products were collected and dried in a vacuum oven at $40{ }^{\circ} \mathrm{C}$ to a constant weight. The routes of copolymerization are shown in Scheme 2.

\section{Results and discussion}

\subsection{Structures of catalysts}

Crystals of the catalysts suitable for single crystal X-ray diffraction were obtained by slow evaporation from dichloromethane solution. The ORTEP plots of Ni2-Ni4 are shown in Fig. 1-3, respectively. The crystallographic data are summarized in Table 1 . The data showed that the crystal systems of Ni2, Ni3 and Ni4 were monoclinic. Selected bond lengths and angles are listed in Table 2. The structure of $\mathrm{Ni} 2$ is mononuclear and a four-coordinate square planar configuration. The center metal ion $\left(\mathrm{Ni}^{2+}\right)$ and the $\mathrm{N}, \mathrm{O}-$ chelator form two stable six-member metallacyclic chelate rings (NiOCCCN). In the solid state, the coordination geometries around nickel atoms are typically square plane where the $\mathrm{N}$ or $\mathrm{O}$ atoms lie in the trans-position and are similar to some known nickel(II) complexes. The benzocyclohexan-ketoimino ligand is stable rigid structure and the catalyst structure is stable and symmetrical, which will be conducive to stable catalytic activity. Crystal structure of Ni2 was shown in Fig. 1. The structures of Ni3 and Ni4 are similar to that of Ni2, and crystal structures are shown in Fig. 2 and 3, respectively.

The ligand electronic effect led to different charge distribution on the nickel metal atom, and the catalytic activity predominantly increased with an increase in the electrophilicity of the nickel metal center. The steric effect of the aryl ring effectively shielded the axial plane of the central metal and suppressed the side reaction of chain growth. The results indicated that the electronic effect of the para-position substituent on the arylimino groups and the steric effect of the aryl ring had a great influence on the catalytic activity.

\subsection{Copolymerization of $\mathrm{NB}$ and $\mathrm{NB}-\mathrm{COOCH}_{3}$}

To further examine the impact of electronic effects on the catalytic activity, Ni1-Ni4 were applied in homo-polymerization of NB as well as copolymerization of $\mathrm{NB}$ and $\mathrm{NB}-\mathrm{COOCH}_{3}$ upon activation with $\mathrm{B}\left(\mathrm{C}_{6} \mathrm{~F}_{5}\right)_{3}$. The detailed data are summarized in Table 3 and were collected under similar conditions. All of the complexes are quite similar and showed high catalytic activity for the copolymerization of $\mathrm{NB}$ and $\mathrm{NB}-\mathrm{COOCH}_{3}$ (up to $2.80 \times$ $10^{5} \mathrm{~g}_{\text {polymer }} \mathrm{mol}_{\mathrm{Ni}}{ }^{-1} \mathrm{~h}^{-1}$ ). Comparing the activities of these catalysts, we found that the activities of $\mathrm{Ni} 3$ and Ni4 containing 


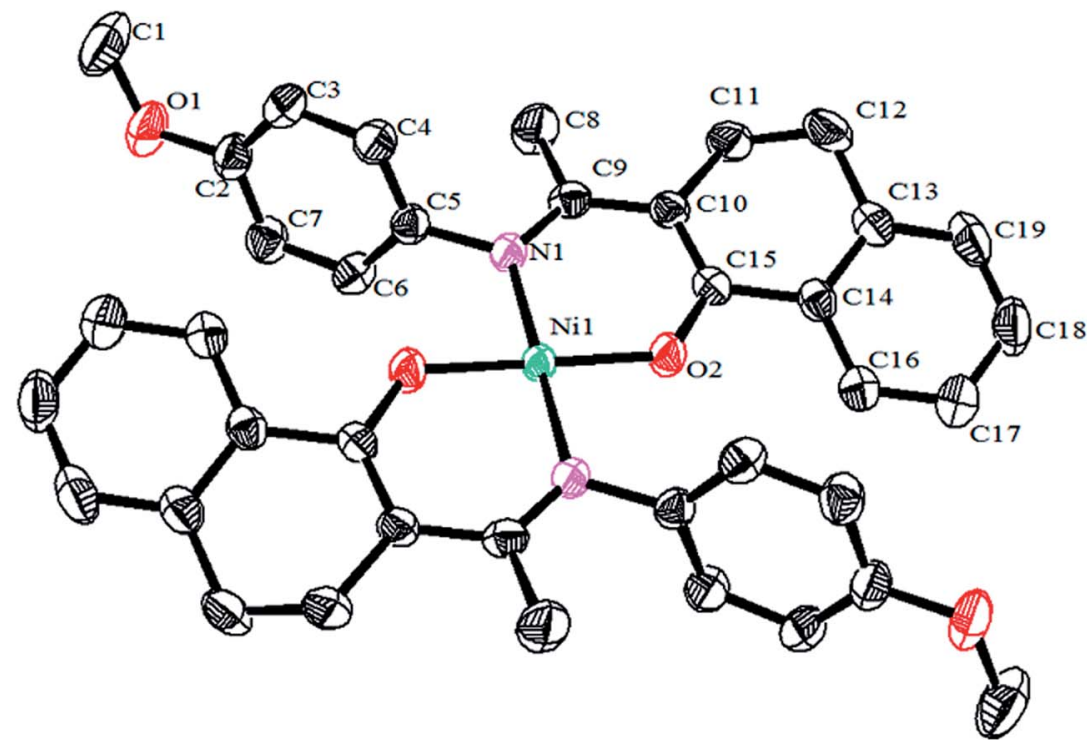

Fig. 1 ORTEP plots of $\mathrm{Ni2}$ showing the crystal structure. Thermal ellipsoids are drawn at the $30 \%$ probability level. Hydrogen atoms are omitted for clarity.

electron-withdrawing groups were higher than those of Ni1 and $\mathrm{Ni} 2$ containing electron-donating groups, and the activity of $\mathrm{Ni} 4$ containing the $-\mathrm{CF}_{3}$ substituent was higher than that for Ni3 containing the $-\mathrm{F}$ substituent, which illustrated that the electron-withdrawing effect was beneficial to the improvement of the catalytic performance. Therefore, the reactivity and

Table 1 Crystal data and structure refinement details for $\mathrm{Ni2}, \mathrm{Ni} 3$ and $\mathrm{Ni} 4$

\begin{tabular}{|c|c|c|c|}
\hline & Ni2 & Ni3 & $\mathrm{Ni} 4$ \\
\hline Empirical formula & $\mathrm{C}_{38} \mathrm{H}_{36} \mathrm{~N}_{2} \mathrm{NiO}_{4}$ & $\mathrm{C}_{36} \mathrm{H}_{30} \mathrm{~F}_{2} \mathrm{~N}_{2} \mathrm{NiO}_{2}$ & $\mathrm{C}_{38} \mathrm{H}_{30} \mathrm{~F}_{6} \mathrm{~N}_{2} \mathrm{NiO}_{2}$ \\
\hline Formula weight & 643.40 & 619.31 & 719.35 \\
\hline Temperature (K) & $293(2)$ & $296(2)$ & 100 \\
\hline Wavelength $(\AA)$ & 0.71076 & 0.71073 & 0.71076 \\
\hline Crystal system & Monoclinic & Monoclinic & Monoclinic \\
\hline$b(\AA)$ & $14.8520(13)$ & $7.111(3)$ & $7.351(3)$ \\
\hline$c(\AA)$ & $7.0027(6)$ & $21.905(8)$ & $24.392(10)$ \\
\hline$\alpha$ (deg) & 90 & 90 & 90 \\
\hline$\beta$ (deg) & $94.988(2)$ & $93.538(9)$ & $94.484(10)$ \\
\hline$\gamma(\mathrm{deg})$ & 90 & 90 & 90 \\
\hline Volume $\left(\AA^{3}\right)$ & $1519.5(2)$ & $1386.2(9)$ & $1558.6(10)$ \\
\hline Crystal size (mm) & $0.22 \times 0.16 \times 0.15$ & $0.24 \times 0.16 \times 0.14$ & $0.20 \times 0.16 \times 0.12$ \\
\hline$\theta$ Range (deg) & 3.108 to 25.500 & 3.42 to 26.00 & 3.239 to 24.795 \\
\hline Limiting indices & $\begin{array}{l}-17 \leq h \leq 17,-17 \leq k \leq 13 \\
-8 \leq l \leq 8\end{array}$ & $\begin{array}{l}-10 \leq h \leq 10,-7 \leq k \leq 8 \\
-27 \leq l \leq 22\end{array}$ & $\begin{array}{l}-10 \leq h \leq 10,-8 \leq k \leq 8 \\
-24 \leq l \leq 28\end{array}$ \\
\hline Refinement method & Full-matrix least-squares on $F^{2}$ & Full-matrix least-squares on $F^{2}$ & Full-matrix least-squares on $F^{2}$ \\
\hline Data/restraints/parameters & $2810 / 0 / 207$ & $2632 / 0 / 197$ & $2618 / 6 / 225$ \\
\hline Goodness-of-fit on $S\left(F^{2}\right)^{a}$ & 1.061 & 0.950 & 1.116 \\
\hline Final $R$ indices $[I>2 \sigma(I)]$ & $R_{1}=0.0304, \mathrm{~W} R_{2}=0.0729$ & $R_{1}=0.0478, \mathrm{~W} R_{2}=0.092$ & $R_{1}=0.0958, \mathrm{~W} R_{2}=0.2224$ \\
\hline$R$ Indices (all data) & $R_{1}=0.0404, \mathrm{~W} R_{2}=0.0759$ & $R_{1}=0.0585, \mathrm{~W} R_{2}=0.1003$ & $R_{1}=0.1224, \mathrm{~W} R_{2}=0.2299$ \\
\hline Largest diff peak and & 0.182 and -0.872 & 0.571 and -0.424 & 1.162 to -0.543 \\
\hline
\end{tabular}

hole $\left(\mathrm{e}^{-3}\right)$

${ }^{a} R=\sum|| F_{\mathrm{o}}|-| F_{\mathrm{c}}|| \sum\left|F_{\mathrm{o}}\right| ; \quad R_{\mathrm{w}}=\left[\sum_{\mathrm{w}}\left(F_{\mathrm{o}}{ }^{2}-F_{\mathrm{c}}{ }^{2}\right)^{2} / \sum_{\mathrm{w}}\left(F_{\mathrm{o}}{ }^{2}\right)^{2}\right]^{1 / 2}$. 
Table 2 Selected bond lengths $(\AA)$ and angles (deg) for Ni2, Ni3 and $\mathrm{Ni} 4$

\begin{tabular}{|c|c|c|c|c|c|}
\hline \multicolumn{2}{|l|}{$\mathrm{Ni} 2$} & \multicolumn{2}{|l|}{$\mathrm{Ni3}$} & \multicolumn{2}{|l|}{$\mathrm{Ni4}$} \\
\hline Bond & Length & Bond & Length & Bond & Length \\
\hline $\mathrm{Ni}(1)-\mathrm{O}(1)$ & $1.8279(11)$ & $\mathrm{Ni}(1)-\mathrm{O}(1)$ & $1.830(2)$ & $\mathrm{Ni}(1)-\mathrm{O}(1)$ & $1.822(5)$ \\
\hline $\mathrm{Ni}(1)-\mathrm{O}(2)$ & $1.8279(11)$ & $\mathrm{Ni}(1)-\mathrm{O}(2)$ & $1.830(2)$ & $\mathrm{Ni}(1)-\mathrm{O}(2)$ & $1.822(5)$ \\
\hline $\mathrm{Ni}(1)-\mathrm{N}(1)$ & $1.9158(14)$ & $\mathrm{Ni}(1)-\mathrm{N}(1)$ & $1.914(2)$ & $\mathrm{Ni}(1)-\mathrm{N}(1)$ & $1.916(7)$ \\
\hline $\mathrm{Ni}(1)-\mathrm{N}(1)$ & $1.9158(14)$ & $\mathrm{Ni}(1)-\mathrm{N}(2)$ & $1.914(2)$ & $\mathrm{Ni}(1)-\mathrm{N}(2)$ & $1.916(7)$ \\
\hline $\mathrm{N}(1)-\mathrm{C}(5)$ & $1.447(2)$ & $\mathrm{C}(4)-\mathrm{N}(1)$ & $1.443(4)$ & $\mathrm{N}(1)-\mathrm{C}(5)$ & $1.430(10)$ \\
\hline Bond & Angle & Bond & Angle & Bond & Angle \\
\hline $\begin{array}{l}\mathrm{O}(2)-\mathrm{Ni}(1) \\
-\mathrm{O}(1)\end{array}$ & 180.0 & $\begin{array}{l}\mathrm{O}(2)-\mathrm{Ni}(1)- \\
\mathrm{O}(1)\end{array}$ & $180.0(11)$ & $\begin{array}{l}\mathrm{O}(1)-\mathrm{Ni}(1)- \\
\mathrm{O}(2)\end{array}$ & $180.0(3)$ \\
\hline $\begin{array}{l}\mathrm{O}(2)-\mathrm{Ni}(1) \\
-\mathrm{N}(2)\end{array}$ & $87.69(6)$ & $\begin{array}{l}\mathrm{O}(2)-\mathrm{Ni}(1)- \\
\mathrm{N}(2)\end{array}$ & $88.03(10)$ & $\begin{array}{l}\mathrm{O}(2)-\mathrm{Ni}(1)- \\
\mathrm{N}(2)\end{array}$ & $88.20(3)$ \\
\hline $\begin{array}{l}\mathrm{O}(1)-\mathrm{Ni}(1) \\
-\mathrm{N}(2)\end{array}$ & $92.31(6)$ & $\begin{array}{l}\mathrm{O}(1)-\mathrm{Ni}(1)- \\
\mathrm{N}(2)\end{array}$ & $91.97(10)$ & $\begin{array}{l}\mathrm{O}(1)-\mathrm{Ni}(1)- \\
\mathrm{N}(2)\end{array}$ & $91.8(3)$ \\
\hline $\begin{array}{l}\mathrm{O}(2)-\mathrm{Ni}(1) \\
-\mathrm{N}(1)\end{array}$ & $92.31(6)$ & $\begin{array}{l}\mathrm{O}(2)-\mathrm{Ni}(1)- \\
\mathrm{N}(1)\end{array}$ & $88.03(10)$ & $\begin{array}{l}\mathrm{O}(2)-\mathrm{Ni}(1)- \\
\mathrm{N}(1)\end{array}$ & $91.8(3)$ \\
\hline $\begin{array}{l}\mathrm{O}(1)-\mathrm{Ni}(1) \\
-\mathrm{N}(1)\end{array}$ & $87.69(6)$ & $\begin{array}{l}\mathrm{O}(1)-\mathrm{Ni}(1)- \\
\mathrm{N}(1)\end{array}$ & $91.97(10)$ & $\begin{array}{l}\mathrm{O}(1)-\mathrm{Ni}(1)- \\
\mathrm{N}(1)\end{array}$ & $88.2(3)$ \\
\hline $\begin{array}{l}\mathrm{N}(2)-\mathrm{Ni}(1) \\
-\mathrm{N}(1)\end{array}$ & 180.0 & $\begin{array}{l}\mathrm{N}(1)-\mathrm{Ni}(1)- \\
\mathrm{N}(2)\end{array}$ & $180.0(15)$ & $\begin{array}{l}\mathrm{N}(1)-\mathrm{Ni}(1)- \\
\mathrm{N}(2)\end{array}$ & 180.0 \\
\hline
\end{tabular}

polymer yield increased with the increasing electronwithdrawing ability of the substituents on the arylimino groups. Beyond that, the activities and polymer yields decreased with the content of $\mathrm{NB}-\mathrm{COOCH}_{3}$ increasing in co-monomers. The phenomenon could be explained by oxygen atoms competing with the double-bond for coordination, and a high concentration of oxygen atoms impedes the coordination of the double-bond.

The poly $\left(\mathrm{NB}-\mathrm{co}-\mathrm{NB}-\mathrm{COOCH}_{3}\right) \mathrm{s}$ were soluble in common organic solvents (such as $\mathrm{CHCl}_{3}, \mathrm{CH}_{2} \mathrm{Cl}_{2}$, cyclohexane, and THF) as well as $o$-dichlorobenzene at room temperature, which exhibited better solubility compared with the PNB.

\subsection{GPC curves of copolymers}

GPC curves of the poly(NB-co-NB-COOCH$\left.)_{3}\right)$ s with different NB$\mathrm{COOCH}_{3}$ incorporation ratios achieved using the Ni1-Ni4/ $\mathrm{B}\left(\mathrm{C}_{6} \mathrm{~F}_{5}\right)_{3}$ systems are shown in Fig. 4 . The molecular weights $\left(M_{\mathrm{w}}\right)$ of the copolymers were all up to the grade of $10^{5}$ and decreased with increasing $\mathrm{NB}-\mathrm{COOCH}_{3}$ content. The poly-dispersity of these copolymers was in the range of 1.66-3.47. The copolymers obtained by Ni4 with wider molecular weight distribution indicated that the higher activity results in different chain growth and termination of polymerization. ${ }^{7}$ Moreover, all copolymers were single modal in the GPC chromatograms, which indicated that copolymerization occurred at single active sites and the products were true copolymers rather than blends of homopolymers.

\section{4 $\quad{ }^{1} \mathrm{H}$ and ${ }^{13} \mathrm{C}$ NMR spectra of copolymers}

The structures of the poly $\left(\mathrm{NB}-\mathrm{co}-\mathrm{NB}-\mathrm{COOCH}_{3}\right) \mathrm{s}$ were characterized by ${ }^{1} \mathrm{H}$ NMR spectra and are shown in Fig. 5, which demonstrated that the polymerization was carried out via vinyl-addition type mechanism by the absence of the resonance of the proton hydrogen connecting to the double bond at about 5.3-6.0 ppm. ${ }^{41}$ The peaks at 3.5-3.8 ppm could be assigned to the hydrogens of $-\mathrm{COOCH}_{3}\left(\mathrm{H}^{\prime}\right)$ and it could be seen that the intensity of the peaks increased with increasing polar comonomer feed ratios. The characteristic peaks at $2.5-2.8 \mathrm{ppm}$ could be attributed to the methine hydrogen corresponding to $\mathrm{H}^{\prime}$, which indicated that the $\mathrm{NB}^{-} \mathrm{COOCH}_{3}$ had accessed to the backbone of norbornene successfully. The peaks at $2.0-2.5 \mathrm{ppm}$ were assigned to the methine hydrogen corresponding to $\mathrm{H} 2 / \mathrm{H}_{3} / \mathrm{H}^{\prime} / \mathrm{H}^{\prime}$ and those at 1.6-2.0 ppm were assigned to the methine hydrogen corresponding to $\mathrm{H} 1 / \mathrm{H} 4 / \mathrm{H} 1^{\prime} / \mathrm{H} 4^{\prime}$. The peaks at $0.7-1.6 \mathrm{ppm}$ could be attributed to the methene hydrogen corresponding to $\mathrm{H} 5 / \mathrm{H} 6 / \mathrm{H7} / \mathrm{H6}^{\prime} / \mathrm{H}^{\prime}$. The molar fractions of $\mathrm{NB}-\mathrm{COOCH}_{3}$ were calculated by ${ }^{1} \mathrm{H}$ NMR analyses and to be 24.9, 22.4, 19.3 and $11.3 \mathrm{~mol} \%$, respectively.

The ${ }^{13} \mathrm{C}$ NMR spectra of the poly(NB-co-NB-COOCH$\left.{ }_{3}\right) \mathrm{s}$ are shown in Fig. 6. Four groups of resonance peaks appeared

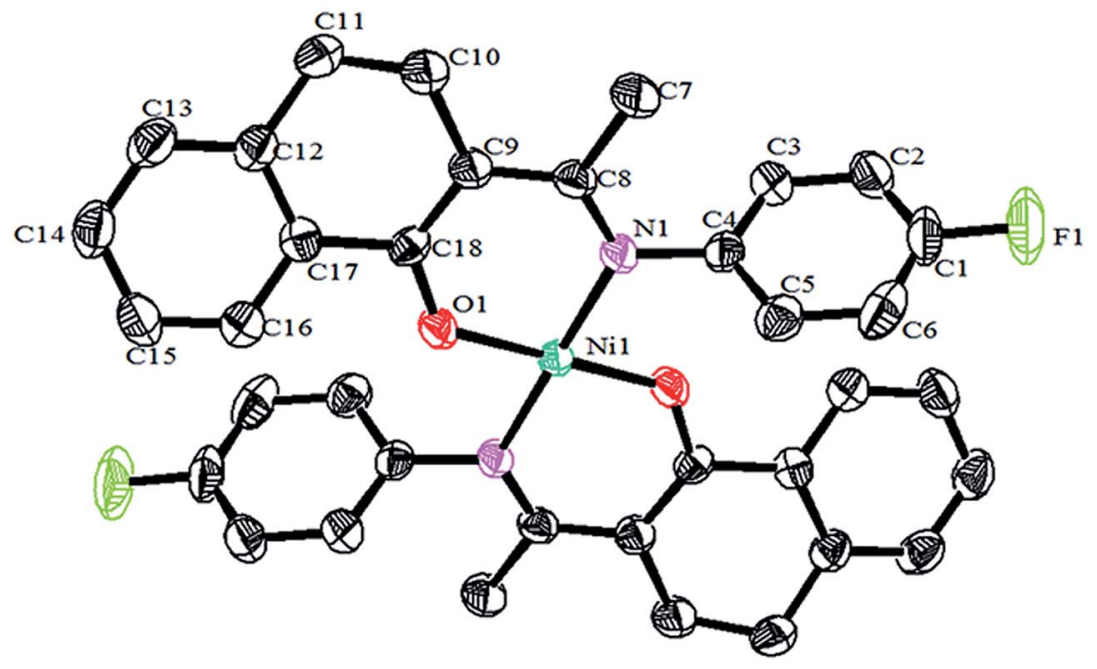

Fig. 2 ORTEP plots of Ni3 showing the crystal structure. Thermal ellipsoids are drawn at the $30 \%$ probability level. Hydrogen atoms are omitted for clarity. 


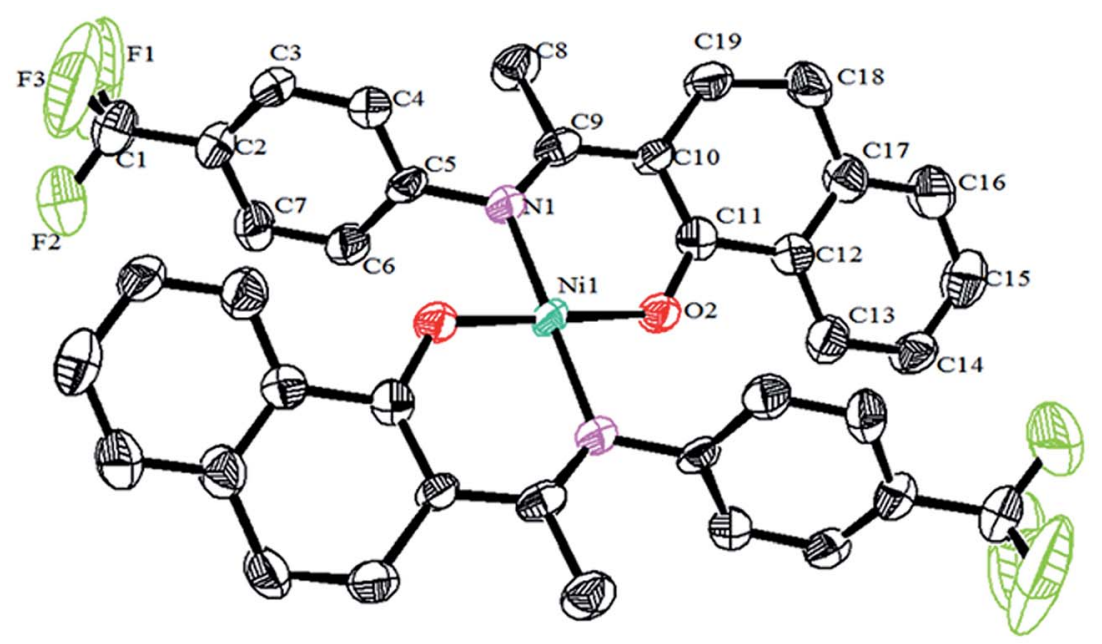

Fig. 3 ORTEP plots of $\mathrm{Ni} 4$ showing the crystal structure. Thermal ellipsoids are drawn at the $30 \%$ probability level. Hydrogen atoms are omitted for clarity.

between 28 and 56 ppm: 28.3-32.5, 33.9-37.8, 38.6-44.7 and 45.1-55.6 ppm, which could be attributed to the methyl, methene or methine carbons corresponding to $\left(\mathrm{C} 5 / \mathrm{C} 6 / \mathrm{C}^{\prime} / \mathrm{C6}^{\prime}\right)$, $\left(\mathrm{C} 7 / \mathrm{C} 7^{\prime}\right),\left(\mathrm{C} 1 / \mathrm{C} 4 / \mathrm{C}^{\prime} / \mathrm{C} 4^{\prime}\right)$ and $\left(\mathrm{C} 2 / \mathrm{C} 3 / \mathrm{C2}^{\prime} / \mathrm{C} 3^{\prime} / \mathrm{C} 9\right)$, respectively. Further, the peaks at $174.2-177.8 \mathrm{ppm}$ were assigned to the $\mathrm{C}=\mathrm{O}$ carbon corresponding to $\mathrm{C} 8$. The absence of $\mathrm{C}=\mathrm{C}$ double bond characteristic peaks at $120 \mathrm{ppm}$ owing to the ROMP-type polymer structures further implied that the copolymerization of $\mathrm{NB}$ and $\mathrm{NB}-\mathrm{COOCH}_{3}$ catalyzed by Ni1-Ni4/B $\left(\mathrm{C}_{6} \mathrm{~F}_{5}\right)_{3}$ was carried out via vinyl addition mechanism.

\subsection{FTIR spectra of copolymers}

The obtained copolymers were also investigated by FTIR spectroscopy (Fig. 7). The characteristic absorption peak signals at about $941 \mathrm{~cm}^{-1}$ could be assigned to the ring of vinyl-type polynorbornene (PNB), as Kennedy and Makowski noted. ${ }^{42}$ There were no absorptions at about $1620-1680 \mathrm{~cm}^{-1}$ and $960 \mathrm{~cm}^{-1}$, which could be attributed to the characteristic trans form of stretching of the $\mathrm{C}=\mathrm{C}$ bond of the structure of ROMPtype PNB. ${ }^{43}$ These results indicated that the polymerization was carried out via vinyl addition mechanism rather than ROMP mechanism. A clear absorption signal of the carbonyl group $(\mathrm{C}=\mathrm{O})$ at $1735 \mathrm{~cm}^{-1}$ in the FTIR spectrum further confirmed the incorporation of $\mathrm{NB}^{-\mathrm{COOCH}_{3}}$ and showed an increase in intensity as the $\mathrm{NB}^{-} \mathrm{COOCH}_{3}$ content increased in the comonomer feed ratios.

\subsection{TGA and DSC analyses of copolymers}

TGA thermograms of poly(NB- $\left.\mathrm{Co}-\mathrm{NB}-\mathrm{COOCH}_{3}\right) \mathrm{s}$ obtained by the Ni1-Ni4/B( $\left(C_{6} F_{5}\right)_{3}$ systems are shown in Fig. 8. All copolymers

Table 3 Copolymerization of NB and NB- $\mathrm{COOCH}_{3}$ catalyzed by Ni1-Ni4 combined with $\mathrm{B}\left(\mathrm{C}_{6} \mathrm{~F}_{5}\right)_{3}{ }^{a}$

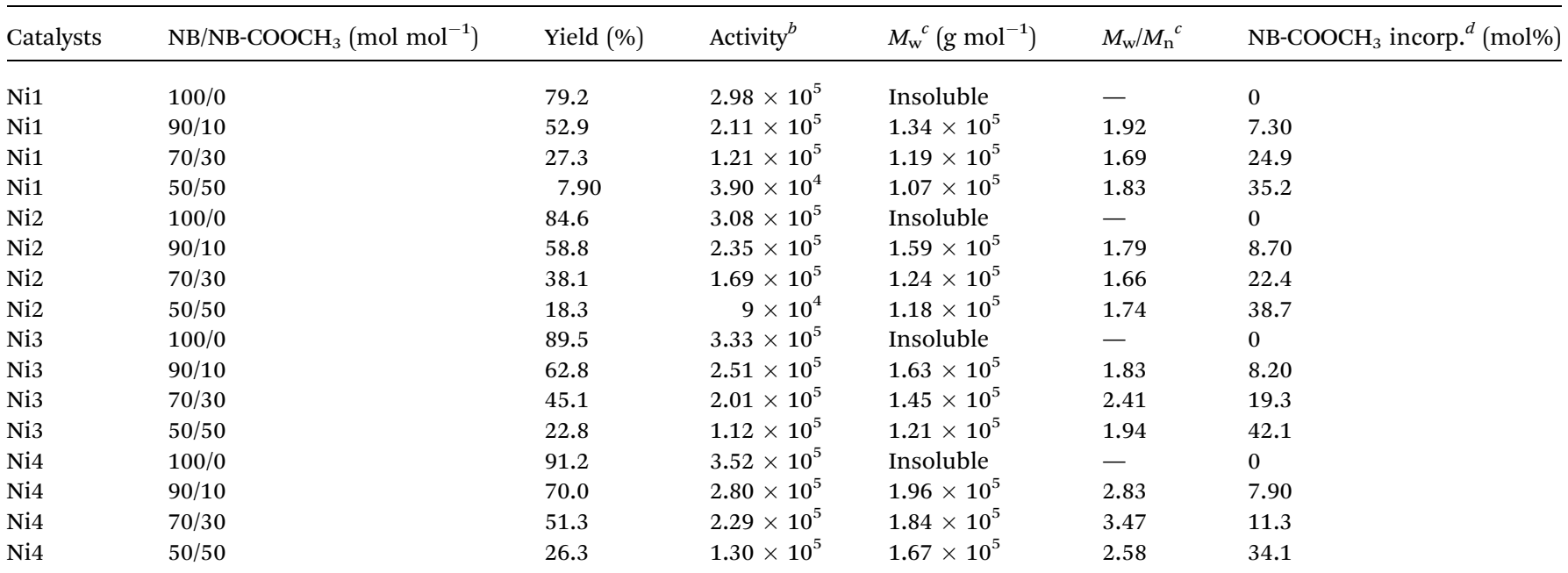

${ }^{a}$ Reaction conditions: $c[\mathrm{Ni}]=5 \mathrm{mmol} \mathrm{L}{ }^{-1} ; n[\mathrm{NB}]+n\left[\mathrm{NB}^{-\mathrm{COOCH}_{3}}\right]=0.01 \mathrm{~mol}$; solvent: toluene; reaction time: 30 min; temperature: $60{ }^{\circ} \mathrm{C} ; n[\mathrm{~B}] / n$ $[\mathrm{Ni}]=20 / 1 .{ }^{b}$ In units of $\mathrm{g}_{\text {polymer }} \mathrm{mol}^{-1} \mathrm{Ni}^{-1} \mathrm{~h}^{c}$ Determined by GPC $v$ s. polystyrene standards in THF. ${ }^{d}$ Determined by ${ }^{1} \mathrm{HNMR}$ spectroscopy in $\mathrm{CDCl}_{3}$. 


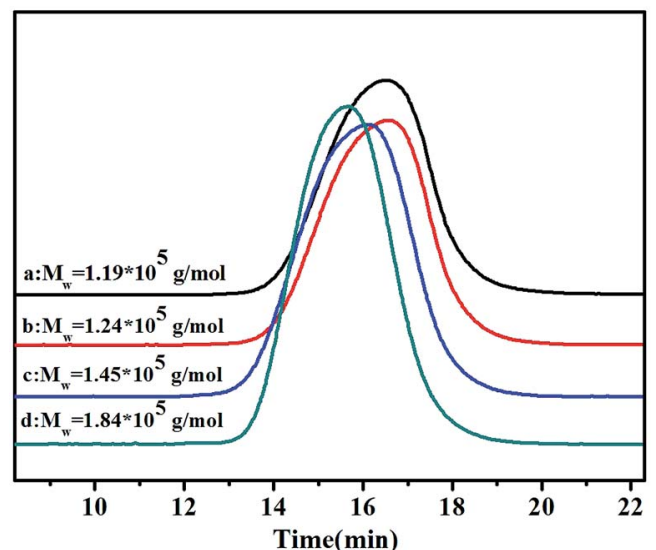

Fig. 4 The GPC curves of poly(NB-CO-NB-COOCH 3 )s with (a) 24.9, (b) 22.4, (c) 19.3, and (d) $11.3 \mathrm{~mol} \% \mathrm{NB}-\mathrm{COOCH}_{3}$ incorporation ratios. (a), (b), (c) and (d) obtained with $\mathrm{Ni1}-\mathrm{Ni} 4 / \mathrm{B}\left(\mathrm{C}_{6} \mathrm{~F}_{5}\right)_{3}$ systems, respectively.

showed similar thermal stability with a decomposition temperature $\left(T_{\mathrm{d}}\right)$ with $5 \%$ weight loss of about $370{ }^{\circ} \mathrm{C}$ that decreased with increasing $\mathrm{NB}^{-\mathrm{COOCH}_{3}}$ content in the

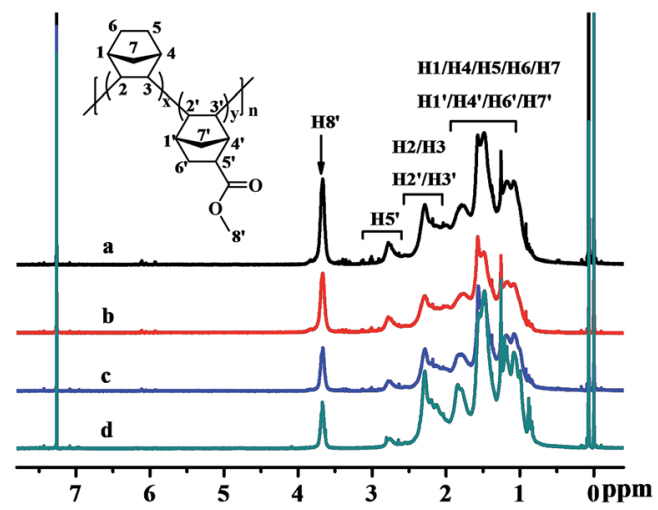

Fig. $5{ }^{1} \mathrm{H}$ NMR spectra of poly(NB-CO-NB-COOCH${ }_{3}$ )s with (a) 24.9, (b) 22.4 , (c) 19.3 , and (d) 11.3 mol\% NB- $\mathrm{COOCH}_{3}$ incorporation ratios. (a), (b), (c) and (d) obtained with $\mathrm{Ni1}-\mathrm{Ni} 4 / \mathrm{B}\left(\mathrm{C}_{6} \mathrm{~F}_{5}\right)_{3}$ systems, respectively.

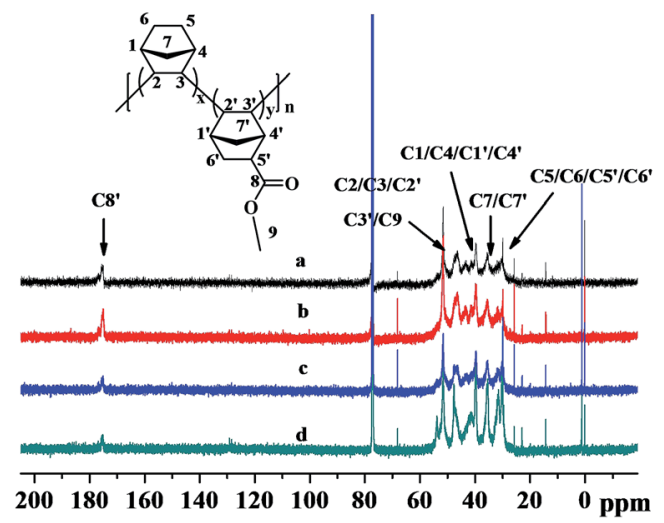

Fig. $6{ }^{13} \mathrm{C}$ NMR spectra of poly(NB-CO-NB-COOCH )s with (a) 24.9, (b) 22.4 , (c) 19.3 , and (d) 11.3 mol\% NB-COOCH 3 incorporation ratios. (a), (b), (c) and (d) obtained with $\mathrm{Ni1}-\mathrm{Ni} 4 / \mathrm{B}\left(\mathrm{C}_{6} \mathrm{~F}_{5}\right)_{3}$ systems, respectively.

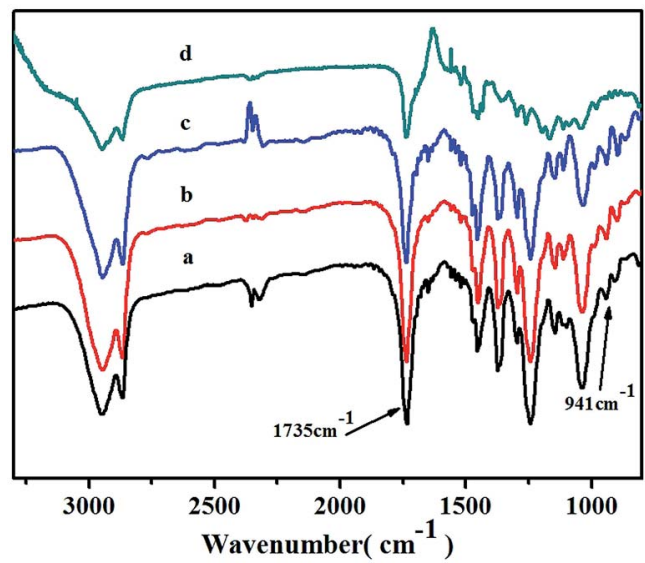

Fig. 7 FTIR spectra of poly(NB-CO-NB-COOCH$)_{3}$ s with (a) 24.9, (b) 22.4, (c) 19.3, and (d) 11.3 mol\% NB- $\mathrm{COOCH}_{3}$ incorporation ratios. (a), (b), (c) and (d) obtained with $\mathrm{Ni1}-\mathrm{Ni} 4 / \mathrm{B}\left(\mathrm{C}_{6} \mathrm{~F}_{5}\right)_{3}$ systems, respectively.

copolymers. Glass transition temperatures $\left(T_{\mathrm{g}}\right)$ of poly(NB-coNB- $\left.\mathrm{COOCH}_{3}\right) \mathrm{s}$ achieved by different catalytic systems were analyzed by DSC and are shown in Fig. 9. The $T_{\mathrm{g}}$ values of the copolymers were about $290^{\circ} \mathrm{C}$ and the trend was similar to that observed for $T_{\mathrm{d}}$. TGA and DSC analyses indicated that copolymers with different $\mathrm{NB}-\mathrm{COOCH}_{3}$ contents obtained using the Ni1-Ni4/B $\left(\mathrm{C}_{6} \mathrm{~F}_{5}\right)_{3}$ systems exhibited good thermal stability under nitrogen.

\subsection{WXRD analyses of the copolymers}

Wide-angle X-ray diffraction analysis of the copolymers catalyzed by the different catalytic systems are shown in Fig. 10. No traces of Bragg reflection in the characteristic crystalline regions were revealed, and therefore the copolymers were noncrystalline. The two halos at $2 \theta$ values of 9.58-10.14 and 18.54-18.83 were characteristic peaks for polynorbornene, and the corresponding distances were obtained according to the equation:

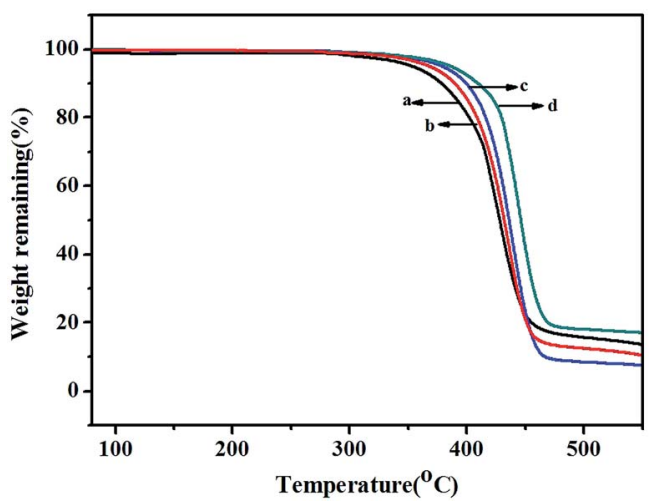

Fig. 8 The TGA thermograms of poly(NB-CO-NB-COOCH )s with (a) 24.9, (b) 22.4, (c) 19.3, and (d) $11.3 \mathrm{~mol} \% \mathrm{NB}-\mathrm{COOCH}_{3}$ incorporation ratios. (a), (b), (c) and (d) obtained with $\mathrm{Ni1}-\mathrm{Ni} 4 / \mathrm{B}\left(\mathrm{C}_{6} \mathrm{~F}_{5}\right)_{3}$ systems, respectively. 


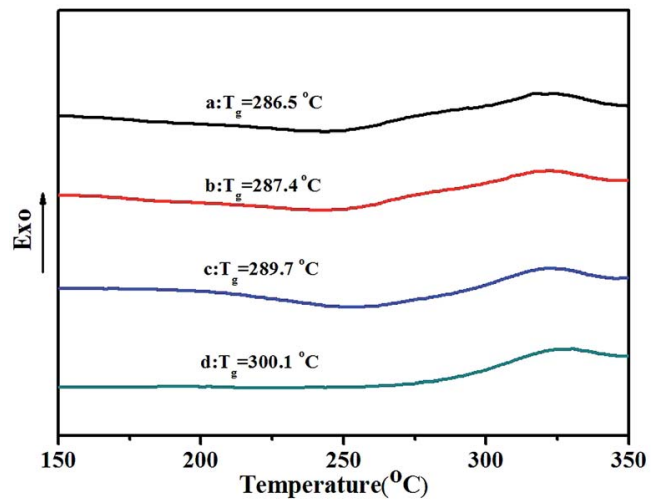

Fig. 9 The DSC curves of poly(NB-CO-NB-COOCH$\left.)_{3}\right)$ with (a) 24.9, (b) 22.4, (c) 19.3, and (d) 11.3 mol\% NB- $\mathrm{COOCH}_{3}$ incorporation ratios. (a), (b), (c) and (d) obtained with $\mathrm{Ni1}-\mathrm{Ni} 4 / \mathrm{B}\left(\mathrm{C}_{6} \mathrm{~F}_{5}\right)_{3}$ system, respectively.

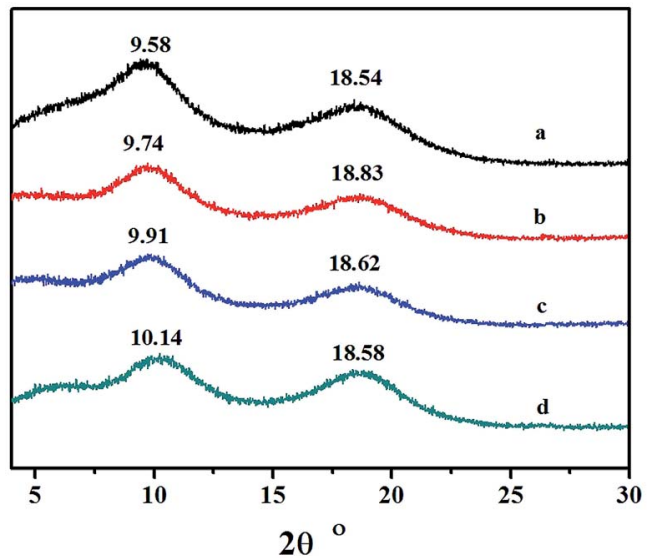

Fig. 10 XRD curves of the obtained NB-co-NB-COOCH${ }_{3}$ copolymers with: (a) 24.9, (b) 22.4, (c) 19.3, and (d) $11.3 \mathrm{~mol} \% \mathrm{NB}-\mathrm{COOCH}_{3}$ incorporation ratios. (a), (b), (c) and (d) obtained with $\mathrm{Ni1}-\mathrm{Ni} 4 / \mathrm{B}\left(\mathrm{C}_{6} \mathrm{~F}_{5}\right)_{3}$ systems, respectively.

$$
d_{\text {interchain }}=1.22 d_{\text {Bragg }}=1.22 \lambda /(2 \sin \theta)
$$

They were $a$ : $11.25 ; b: 11.07 ; c: 10.88$; and $d: 10.63 \AA$, respectively. The results indicated that the packing density of copolymer obtained by different catalytic systems was fairly consistent.

\section{Conclusions}

Four N,O-chelating type bidentate ligand nickel complexes (Ni1-Ni4) bearing different electronic effects $\left(-\mathrm{CH}_{3},-\mathrm{OCH}_{3},-\mathrm{F}\right.$ and $-\mathrm{CF}_{3}$ ) were synthesized. Ni2-Ni4 were characterized by single crystal X-ray diffraction, and the copolymerization of norbornene and 5-norbornene-2-carboxylic acid methyl ester in the presence of $\mathrm{B}\left(\mathrm{C}_{6} \mathrm{~F}_{5}\right)_{3}$ was examined. All complexes showed high catalytic activity toward the copolymerization (up to $2.80 \times$ $10^{5} \mathrm{~g}_{\text {polymer }} \mathrm{mol}_{\mathrm{Ni}}{ }^{-1} \mathrm{~h}^{-1}$ ) and the activity order was $\mathrm{Ni} 4>\mathrm{Ni} 3>$ $\mathrm{Ni} 2>\mathrm{Ni1}$, which illustrated that the electron-withdrawing effect was beneficial to the improvement of the catalytic performance and the activity was improved with increasing electronattractive ability of the substituent. The analyses of the copolymer structures and properties indicated that the polymerization was carried out via vinyl addition mechanism rather than ROMP mechanism. The poly(NB- $\left.\mathrm{CO}-\mathrm{NB}-\mathrm{COOCH}_{3}\right) \mathrm{s}$ exhibited better solubility than that of the PNB and showed high molecular weights (up to a grade of $\left.10^{5}\right)$ and thermal stability $\left(T_{\mathrm{d}}>370{ }^{\circ} \mathrm{C}\right)$. The poly(NB-co-NB-COOCH$\left.{ }_{3}\right) \mathrm{s}$ were confirmed to be noncrystalline. Meanwhile, variation of the substituted electron group could slightly affect the properties of the above-mentioned copolymers.

\section{Conflicts of interest}

There are no conflicts to declare.

\section{Acknowledgements}

This work was supported by the National Natural Science Foundation of China (21164006 and 21674045).

\section{References}

1 A. Ravasio, C. Zampa, L. Boggioni, I. Tritto, J. Hitzbleck and J. Okuda, Macromolecules, 2008, 41, 9565-9569.

2 X. H. He, Y. W. Chen, Y. M. Liu, S. X. Yu, S. G. Hong and Q. Wu, J. Polym. Sci., Part A: Polym. Chem., 2007, 45, 47334743.

3 I. Tritto, L. Boggion and D. R. Ferro, Coord. Chem. Rev., 2006, 250, 212-241.

4 Y. I. Denisova, M. L. Gringolts, A. V. Roenko, G. A. Shandryuk, E. S. Finkelshtein and Y. V. Kudryavtsev, Mendeleev Commun., 2017, 27, 416-418.

5 H. J. Yang, W. H. Sun, F. Chang and Y. Li, Appl. Catal., A, 2003, 252, 261-267.

6 C. Janiak and P. G. Lassahn, J. Mol. Catal. A: Chem., 2001, 16, 193-209.

7 W. H. Sun, H. J. Yang, Z. L. Li and Y. Li, Organometallics, 2003, 22, 3678-3683.

8 X. H. He, Y. J. Deng, X. Jiang, Z. J. Wang, Y. P. Yang, Z. L. Han and D. F. Chen, Polym. Chem., 2017, 8, 2390-23396.

9 M. Hollauf, M. Cajlakovic, M. Tscherner, S. Köstler, A.-C. Knall and G. Trimmel, Monatsh. Chem., 2017, 148, 121-129.

10 M. Chen and C. L. Chen, ACS Catal., 2017, 7, 1308-1312.

11 Z. X. Wu, M. Chen and C. L. Chen, Organometallics, 2016, 35, 1472-1479.

12 X. H. He, Y. J. Deng, Z. L. Han, Y. P. Yang and D. F. Chen, J. Polym. Sci., Part A: Polym. Chem., 2016, 54, 3495-3505.

13 M. Schneider, J. Claverie, C. Graillat and T. F. Meckenna, J. Appl. Polym. Sci., 2002, 84, 1878-1896.

14 K. Ziegler, E. Holzkamp, H. Breil and H. Martin, Angew. Chem., 1955, 67, 541-547.

15 L. P. He, J. Y. Liu, Y. G. Li, S. R. Liu and Y. S. Li, Macromolecules, 2009, 42, 8566-8570.

16 R. M. Golding, R. O. Pascual, C. Suvanprakorn and I. G. Dance, Bull. Korean Chem. Soc., 2006, 27, 1752-1756. 
17 W. Kaminsky, S. Derlin and M. Hoff, Polymer, 2007, 48, 7271-7278.

18 H. J. Yang, Z. L. Li and W. H. Sun, J. Mol. Catal. A: Chem., 2003, 206, 23-28.

19 F. Bao, X. Lü and Y. Chen, Polym. Bull., 2007, 58, 495-502.

20 Y. M. Xu, K. Li, Y. H. Wang, W. Deng and Z. J. Yao, Polymers, 2017, 9, 105-115.

21 A. A. Antonov, N. V. Semikolenova, V. A. Zakharov, W. J. Zhang, Y. H. Wang, W. H. Sun, E. P. Talsi and K. P. Bryliakov, Organometallics, 2012, 31, 1143-1149.

22 H. Y. Gao, L. X. Pei, Y. F. Li, J. K. Zhang and Q. Wu, J. Mol. Catal. A: Chem., 2008, 280, 81-86.

23 J. J. Lai, X. H. Hou, Y. W. Liu, C. Redshaw and W. H. Sun, J. Organomet. Chem., 2012, 702, 52-58.

24 X. F. Li and Y. S. Li, J. Polym. Sci., Part A: Polym. Chem., 2002, 40, 2680-2685.

25 D. P. Song, X. C. Shi, Y. X. Wang, J. X. Yang and Y. S. Li, Organometallics, 2012, 31, 966-975.

26 F. Bao, X. Q. Lue, Y. Q. Qiao, G. Q. Gui, H. Y. Gao and Q. Wu, Appl. Organomet. Chem., 2005, 19, 957-963.

27 H. Y. Gao, J. K. Zhang, Y. Chen, F. M. Zhu and Q. Wu, J. Mol. Catal. A: Chem., 2005, 240, 178-185.

28 C. Carlini, M. Martinelli, G. Raspolli, M. Anna and G. Sbrana, J. Polym. Sci. Part A: Polym. Chem., 2006, 44, 1514-1521.

29 M. R. Radlauer, M. W. Day and T. Agapie, J. Am. Chem. Soc., 2012, 134, 1478-1481.

30 J. W. Tian, H. Y. Zhu, J. Y. Liu, D. F. Chen and X. H. He, Appl. Organomet. Chem., 2014, 28, 702-711.
31 D. P. Song, W. P. Ye, Y. X. Wang, J. Y. Liu and Y. S. Li, Organometallics, 2009, 28, 5697-5704.

32 D. P. Song, J. Q. Wu, W. P. Ye, H. L. Mu and Y. S. Li, Organometallics, 2010, 29, 2306-2314.

33 Y. Z. Zhu, J. Y. Liu, Y. S. Li and Y. J. Tong, J. Organomet. Chem., 2004, 689, 1295-1303.

34 X. H. He, Y. Z. Yao, X. Luo, J. K. Zhang, Y. H. Liu, L. Zhang and Q. Wu, Organometallics, 2003, 22, 4952-4957.

35 Y. P. Xing, Y. W. Chen and X. H. He, J. Polym. Sci., Part A: Polym. Chem., 2011, 49, 4425-4432.

36 Y. P. Xing, X. H. He, Y. W. Chen, H. R. Nie and Q. Wu, Polym. Bull., 2011, 66, 1149-1161.

37 X. H. He, Y. M. Liu, C. Lu, Y. W. Chen and D. F. Chen, J. Polym. Sci., Part A: Polym. Chem., 2012, 50, 4695-4704.

38 L. Chen, Z. C. Zhong, C. Chen, X. H. He and Y. W. Chen, J. Organomet. Chem., 2014, 752, 100-108.

39 J. W. Tian, X. H. He, J. Y. Liu, X. D. Deng and D. F. Chen, $R S C$ $A d v .$, 2015, 5, 61851-61860.

40 X. H. He, Y. Z. Yao, X. Luo, J. K. Zhang, Y. H. Liu, L. Zhang and Q. Wu, Organometallics, 2003, 22, 4952-4957.

41 M. C. Sacchi, M. Sonzogni, S. Losio, F. Forlin, P. Locatelli, I. Tritto and M. Licchelli, Macromol. Chem. Phys., 2001, 202, 2052-2058.

42 J. P. Kennedy and H. S. Makowski, J. Macromol. Sci., Chem., 1967, 1, 345-370.

43 T. Tsujino, T. Saeguss and J. Furukawa, Macromol. Chem., 1965, 85, 71-79. 